7. Аналітичні довідки МВС України за 1996-1999 pp. «Про стан роботи паспортної служби органів внутрішніх справ України по лінії контролю за перебуванням іноземців на території держави»

DOI https://doi.org/10.30525/978-9934-26-074-2-37

\title{
ДИНАМІЧНІСТЬ ПРИНЦИПІВ ТА МАКРОФУНКЦІЇ АДМІНІСТРАТИВНОГО СУДОЧИНСТВА
}

\author{
Остафійчук Л. А. \\ кандидат юридичних наук, \\ доиент кафедри процесуального права \\ Чернівецького національного університету імені Юрія Федьковича
} м. Чернівиі, Україна

Соціальне призначення i сутність права та адміністративного судочинства розкривається i конкретизується в їх принципах та функціях. Чи є ці принципи однаковими для права загалом, чи все ж таки кожна галузь права має свої особливі, притаманні лише їй принципи? Сучасний дослідник процесуального права В. М. Протасов зазначив, що «загальна теорія права в іiї сучасному стані індиферентна до різниці між матеріальним i процесуальним правом при оцінці правових явищ $\mathrm{i}$ більшою мірою іiі можна вважати «теорією матеріального права» [11, с. 18]. Проте, А. О. Павлушина слушно зауважила, що в рамках обговорюваної теорії не було належним чином враховано самостійну змістовну цінність норм процесуального права, тому що автори наполягали, що процесуальні норми є похідними від матеріальних [9, с. 31]. Далі виникла концепція судового права (1980 р.), яка мала б об'єднати кримінальний і цивільний процеси, а пізніше й судоустрій. Але, як показала практика розвитку галузевих наук, - цього не відбулося, та й не могло відбутися. Хоча, наприклад, - судова система і судочинство як країн загального права, так і держав, правосистема яких відноситься до континентальної правової сім'ї, будуються на розумінні високого ступеню спільності судових процедур, основою яких $\epsilon$ обов'язковий набір принципів i норм, які забезпечують конкретне положення особи в процесі. Крім цього, в конституціях більшості західних держав, загальні принципи i правила здійснення правосуддя визначені по відношенню до правосуддя в цілому, незалежно від конкретної процесуальної форми, особливості якої виражені в різних процесуальних кодексах [9, с. 38-40]. Отже в цій частині нашого 146 
дослідження ми можемо зробити висновок про те, що 1) принципи процесу історично виділилися із принципів матеріального права; 2) принципи процесу в більшій своїй частині $\epsilon$ спільними для всіх видів процесу; 3) принципи конкретного виду судового процесу, в тому числі адміністративного судочинства відображають його змістовну єдність.

Свого часу Р. Дворкін наголошував, що суб'єкти права мають брати принцип до уваги там, де він доречний. а також, що він орієнтуватиме їх у тому чи іншому напрямку [6, с. 50-52]. I саме в процесі судового правозастосування, на думку В. В. Сршова, принципи права, як більш загальна категорія, інтегруються у вигляді обов'язкових принципів судочинства [7, с. 159-160]. Принципи судочинства є такими, що конкретизують принципи права знаходять своє вираження в більш конкретних нормах, забезпечуючи правовий характер судової практики. В свою чергу, принципи судочинства утворюють свою систему, де один принцип також виводиться зі змісту іншого [12, с. 6-8], зауважує О. С. Сідоркін. Як бачимо, принципи права і принципи адміністративного судочинства поєднані між собою, і мають розумітися як система правових норм найбільш загального характеру, що володіють високим рівнем абстракції, відображають такі сутнісні властивості права як свобода, формальна рівність і справедливість.

На принципах права формується динаміка і дія права, що дозволяє, за твердженням М. І. Байтіна, визначити правову природу цього права, як демократичного чи тоталітарного [2, с. 148]. Поєднання в одній і тій самій системі норм як статичних так і динамічних принципів досліджував Г. Кельзен. Вчений зауважив, що іноді засаднича норма за динамічним принципом запроваджує лише один нормовстановчий авторитет, але далі ця норма чи встановлений нею авторитет «запроваджує не лише такі норми, в яких делегуються інші нормовстановчі авторитети, а й такі, якими регламентується певна поведінка підпорядкованих нормі суб'єктів i $з$ яких - ніби часткове із загального - можна виводити шляхом логічної операції подальші норми» [8, с. 219].

Дійсно, сучасний розвиток суспільства диктує правила, за якими принципи права змушені динамічно розвиватися та розкриватися з різних сторін. Це явище можна пояснити глобалізацією та впливом і взаємопроникненням різних правових систем, як, наприклад, вплив практики рішень ЄСПЛ на право та судівництво в Україні. На динамічний розвиток принципів права і процесу (судочинства) звернули увагу I. М. Балакарєва, I. В. Бойко та О. О. Марченко, які відзначили, що ЄСПЛ постійно збагачує принцип верховенства права новим змістом, розкриваючи у своїх рішеннях його сутність через формулювання вимог, які він виводить із принципу [1, с. 32]. До елементів верховенства права 
наразі відносять: 1) законність, включно з прозорим, підзвітним і демократичним процесом прийняття нормативно-правових актів; 2) правову визначеність; 3) заборону довільності у прийнятті рішень або захист проти свавілля суб'єктів владних повноважень; 4) забезпечення доступу до правосуддя, що здійснюється належним та безстороннім судом, включно з можливістю оскаржити в суді будь-які адміністративні акти; 5) повагу до прав людини; 6) недискримінацію та рівність перед законом [4, с. 177-181]. Вказаний приклад і є яскравим підсумком нашої тези, що принципи $є$ динамічними, так як розвиваються, вдосконалюються, наповнюються новим змістом шляхом виокремлення його елементів. Отже, принципи адміністративного судочинства слід розглядати як самостійні, змістовно-цінні динамічні нормативні приписи, спрямовані на якісну організацію та справедливе здійснення правосуддя в справах адміністративної юрисдикції.

В монографічному дослідженні основоположних принців права С. П. Погребняк звертає увагу на макрофункції права, які досліджував С. Бурлай. Зокрема, «макрофункцією права як суспільного регулятора охоплюється ціла низка його більш конкретних функцій, що здійснюються комплексно, одночасно та внаслідок цього організовують і стабілізують суспільство» [10, с. 6-7].

За подібною логікою, ми можемо виділити й макрофункції адміністративного судочинства, яке першочергово покликано за допомогою судових органів захистити права, свободи та інтереси фізичних осіб, права та інтереси юридичних осіб від свавілля з боку суб'єктів владних повноважень, в широкому тлумаченні цього терміну, наданого в п.7 ч. 1 ст. 4 Кодексу адміністративного судочинства України (далі - КАС України).

Функція «соціальної стабілізації» в адміністративному судочинстві буде втілюватися в соціальному захисті різних верств населення у сфері публічно-правових відносин від порушень 3 боку суб'єків владних повноважень (ч. 2 ст. 5 КАС України).

Відновлювальна (компенсаційна) функція, на думку Т. О. Голоядової, полягає у відновленні незаконно порушених прав та майнових благ потерпілої особи. Це питання досліджувалось у працях Д. М. Бахраха, М. Я. Масленнікова і О. І. Миколенка, які зійшлися в думці, що відновлювальна (компенсаційна) функція притаманна й адміністративній відповідальності, хоча в меншому ступені ніж це відбувається в межах цивільно-правової відповідальності [5]. Відновлювально-компенсаційна функція більшою мірою пов'язана із юридичною відповідальністю і в повній мірі стосується адміністративного судочинства, так як в порядку КАС України розглядаються адміністративні справи з приводу 
рішень, дій чи бездіяльності суб'єктів владних повноважень у справах про притягнення до адміністративної відповідальності (ст. 286 КАС України).

Функція засобу соціальної відплати тлумачиться С. Білозьоровим як каральна, штрафна, пенальна, яка чинить вплив як акт відплати держави щодо правопорушника, а також виступає як засіб, що запобігає новим правопорушенням [3, с. 50-54]. В адміністративному судочинстві це категорії адміністративних справ щодо затримання іноземців або осіб без громадянства (ст. 289 КАС України), примусового видворення іноземців або осіб без громадянства за межі території України (ст. 288 КАС України), накладення арешту на активи, що пов'язані з фінансуванням тероризму та стосуються фінансових операцій, зупинених відповідно до рішення, прийнятого на підставі резолюцій Ради Безпеки $\mathrm{OOH}$, зняття арешту з таких активів та надання доступу до них (ст. 284 КАС України).

Таким чином, функції права й адміністративного судочинства забезпечують авторитет права шляхом сприйняття його як справедливого та корисного регулятора, а за допомогою державного примусу забезпечується підтримання обов'язковості права для всіх.

\section{Література:}

1. Адміністративне судочинство: навч. посіб. І.М. Балакарєва, I. В. Бойко, Я.С. Зелінська та ін.. За заг. ред. Н.Б. Писаренко. Х.: Право, 2016. $312 \mathrm{c}$.

2. Байтин М.И. Сущность права (Современное нормативное правопонимание на грани двух веков). Изд. 2-е, доп. М.: ООО ИД «Право и государство», 2005. 544 с.

3. Білозьоров $€$. Юридична відповідальність як передумови правомірної поведінки особи: теоретичні аспекти. Право Украӥни, 2006. № 1. С. 50-54.

4. Верховенство права. Доповідь, схвалена Венеційською Комісією на 86-му пленарному засіданні (Венеція, 25-26 березня 2011 року). Право України, 2011. № 10. С. 168-184.

5. Голоядова Т.О. Поняття та види функцій адміністративної відповідальності. URL: http://dspace.onua.edu.ua/bitstream/handle/11300/ 258/app-37_Goloyadova_T_O_\%2883-92\%29.pdf?sequence=1\&isAllowed=y

6. Дворкін Р. Серйозний погляд на права: Пер. $з$ англ. К.: Основи, $2000.519 \mathrm{c}$.

7. Ершов В. В. Юридическая природа общих и гражданско-правовых принципов: Дис. ... канд. юрид. наук: 12.00.01, 12.00.03. М., 2009. 197 с. 
8. Кельзен Ганс. Чисте Правознавство: 3 дод.: Проблеми справедливості. Пер. $з$ нім. О. Мокровольського. К.: Юніверс, 2004. 496 с.

9. Павлушина А.А. Теория юридического процесса: итоги, проблемы, перспективы развития. М.: Издательство «Юрлитинформ», 2009. $472 \mathrm{c}$.

10. Погребняк С.П. Основоположні принципи права (змістовна характеристика): Монографія. Х.: Право, 2008. 240 с.

11. Протасов В.Н. Основы общеправовой процессуальной теории. М.: Юридическая литература, 1991. 143 с.

12. Сидоркин А.С. Принципы права: понятие и реализация в российском законодательстве и судебной практике: дис. ... канд. юрид. наук: 12.00.01. М., 2010. 197 с.

DOI https://doi.org/10.30525/978-9934-26-074-2-38

\title{
ПРОЦЕСУАЛЬНЕ ОФОРМЛЕННЯ ЕТАПУ ПІДГОТОВКИ ДО РОЗГЛЯДУ СПРАВИ ПРО АДМІНІСТРАТИВНЕ ПРАВОПОРУШЕННЯ: НАПРЯМИ ЗАКОНОДАВЧОГО ВРЕГУЛЮВАННЯ
}

\author{
Романенко I. B. \\ кандидат юридичних наук, \\ доиент кафедри загальноправових дисииплін \\ Національної академії Служби безпеки Украӥни \\ Прогонюк М. C. \\ курсант \\ Національної академії Служби безпеки України \\ м. Київ, Украӥна
}

Здійснюючи правосуддя, суди керуються верховенством права. При цьому ї метою є своєчасне, всебічне, повне і об'єктивне з'ясування обставин кожної справи, вирішення ії в точній відповідності з законом, забезпечення виконання винесеної постанови, а також виявлення причин та умов, що сприяють вчиненню адміністративних правопорушень, запобігання правопорушенням, виховання громадян у дусі додержання законів, зміцнення законності [1, ст. 245].

Етап підготовки справи до розгляду часто визначається як невід'ємна складова стадії розгляду й винесення постанови по справі. Основні 